naming of plants must always be helpful in assembling and disseminating information, but a very general classification on obvious features like the rate of growth, habit of growth, both above and below ground, texture of tissues and similar factors is quite adequate for the purpose in hand." But how on earth is a "practical planter", or anyone else, to "study competition" when he does not know the names of the competing species? Also how will a "very general classification" of the kind described help him here? It is obvious enough that it does not matter what language the names belong to-Latin, English or Malay(though the scientific names have well-known advantages), provided the same name is always used for the same species and for that species alone; but names in some language are quite indispensable. The planter must learn the names of the important species on his estate (or give them names of his own) before he can advance a single step in studying competition or increasing his knowledge in any way of what is going on in his plantations, once he lets in the native plants. Naturally, it is not necessary for him to acquire an exhaustive knowledge of the whole flora. When he has learned to distinguish the important species, then he can most usefully pay attention to their characters and behaviour under different conditions.

This, of course, is nothing but ecology, and we very much regret to see that, though Mr. Haines himself admits (p. 1) that "many of the problems which arise regarding natural covers are ecological", Mr. B. J. Eaton in his foreword summarises "the advantages of natural covers" solely in relation to their effect on soil, and writes that "for a study of this aspect of the problem the employment of a Forester or of a Plant Eeologist, as has been suggested in some quarters, is not essential". Well, the rubber industry may survive without such appointments, but that the whole problem is essentially ecological there can be no shadow of doubt. The soil problems as such, though an extremely important part of the whole, by no means exhaust the matter, as Mr. Haines is clearly aware, witness his constant stress on competition.

The general recognition of the fundamental importance of the ecological approach wherever we have to deal with communities of organisms living together is gradually coming, though it is distressingly slow. The ecologist is trained to consider the whole set of phenomena presented by such communities, and to discover which are of decisive and which of subordinate importance. Only when such knowledge has been acquired in any given case can the problem of rational treatment be successfully attacked. There are now young ecologists available-as there were not ten years ago-who have had this training, and it remains for the competent authorities to see that their services are employed in tackling the innumerable problems that await rational solution.

Specialists who have had a narrower training and very naturally think that 'there's nothing like leather', very often fail to come to grips with the larger aspects of their problems because they envisage them solely from one side. Ecologists can sometimes indicate the best solutions as soon as their survey of the field is completed, but very often experiment and specialised work are necessary after the general survey is completed. This is the proper sphere of the specialist, be he plant physiologist, mycologist, entomologist, pedologist or soil chemist. Ecologists have now been successfully engaged in the solution of the most various practical problems in New Zealand, in South Africa, in the United States, and elsewhere, but the fields ripe for their work are innumerable, and the proper management of the modern rubber plantation is clearly one of them.

A. G. T.

\title{
Economy of Transport Overseas
}

$\mathrm{M}^{\mathrm{B}}$ ERCANTILE vessels can be divided into three main classes-passenger ships, combined passenger and cargo ships and purely cargo ships. Of these it is the first class which receives the greatest attention in the public Press ; although the commerce of the world is carried on principally by tramps and freighters, these are seldom in the public eye. Generally speaking, unlike the steam locomotive, which was first used for mineral traffic before its potentialities for passenger traffic had been realised, the steam boat was regarded chiefly as a passenger carrying vessel.

The idea that steam vessels might prove of use for freight carrying, however, was not altogether absent from the minds of the pioneers, and a century and a half ago the oft-forgotten but deserving American inventor John Fitch wrote, "Here is an estimate which I beg leave to make. It takes thirty men to take a boat of thirty tons burthen from New Orleans to the Illinois. Now, I say, if I could be enabled to complete the experiment, I would obligate myself to make a boat of sixty tons burthen which, with engines and all complete, would cost $\$ 2,000$. As that could work double the time of the men at the oars, it could go half the time, and transport 120 tons in the same time that the other would thirty tons. At the rate now charged this would pay for 
itself and clear $\$ 10,000$ whilst one boat could make one trip-and larger boats could be made to greater advantage".

Fitch was a man of wide vision who did not live to see his dreams come true. He has, however, as great a claim as anyone to be regarded as the father of the steam passenger boat and the steam cargo boat. But while conceding this, it is true that both in the United States and in Europe, when steamboats came into use, it was passenger traffic which was regarded as the principal source of revenue.

The traffic which, perhaps, led to the construction of the first cargo steamers in Europe was the cattle trade between Ireland and England, and just a century ago the Glasgow Chronicle referred to the Clyde-built steamer Irishman plying between Drogheda and Liverpool, which was capable of carrying 2,000 head of cattle, and was fitted with stalls for horses and horned cattle and pens for pigs, etc., on deck and in the hold. There was certainly need for improvement in this trade, for Joshua Field in his "Diary" of a visit to Liverpool in 1821 said that during a storm in the Irish Sea in September, " 6 or 8 Brigs full of horned cattle and pigs were out in it and I believe all came in during the following day having lost more or less of the cattle killed in the hold and pigs either killed on deck or washed overboard. One of them lost 60 pigs overboard and one 70 and the captain. They came in mostly on their beam ends, the cattle dead and alive being on one side".

Another traffic which gave rise to steam cargo vessels was the carriage of coal from the Tyne to the Thames. In 1844, a Tyneside shipbuilder built an iron screw collier with a deadweight capacity of 340 tons, while eight years later Sir Charles Palmer at Jarrow built the larger John Bowes, carrying 650 tons. The John Bowes could make the voyage from Newcastle to London and back in five days and thus "she accomplished an amount of work it would have taken two averagesized sailing-colliers a month to perform". To the success of the John Bowes may, to some extent, be attributed the subsequent rapid development of iron shipbuilding on the north-east coast, a district famous for its construction of tramps and freighters. Similar vessels are to-day built in many yards all over the world and from these yards come not only ships ready to carry any form of general merchandise but also others especially designed for the transport of fruit, meat, grain, coal, ore, oil and other commodities. The greater part of the world's mercantile marine is indeed composed mainly of these cargo ships, of which little is heard.

It has been considered worth while to give this brief sketch of the early history of eargo ships because it was with tramps and freighters that Mr. L. St. L. Pendred was concerned in the most valuable part of his Thomas Lowe Gray Lecture delivered to the Institution of Mechanical Engineers on November 30 (see Nature, Dec. 8, p. 875). The title of his lecture, "A Survey of Ships and Engines", left him free to touch upon many aspects of shipbuilding and marine engineering; and in the earlier part he pointed out some of the landmarks in steamship history up to the time when improvements in both ships and engines had enabled cargoes to be carried long distances more economically by steam than by sail.

Having got thus far, Mr. Pendred devoted himself exclusively to cargo steamers. He had been at some pains to obtain from authoritative sources particulars of ships of the last fifty or sixty years, and his lecture contains two tables, prepared, one by Mr. T. W. Crozier, for many years manager of the Blyth and Tyne Shipbuilding Co., and another by Mr. Summers Hunter, giving particulars of merchant steamers engined between 1867 and 1934 by the North-Eastern Marine Engineering Co. With the aid of these tables, Mr. Pendred had prepared a series of curves connecting coal consumption, steam pressures, speéd, etc. The progress of tramps, however, he summarised as follows. In 1887 a typical tramp was $285 \mathrm{ft}$. long, with a displacement of 4,840 tons. The working pressure was $160 \mathrm{lb}$. per sq. in. and the speed $9 \frac{3}{4}$ knots. In 1896 the length had risen to $325 \mathrm{ft}$. and the displacement to 7,075 tons. By 1911 the displacement had risen to 10,000 tons, by 1924 to 11,500 tons and by 1928 to 12,380 tons. Boiler pressures had risen to $200 \mathrm{lb}$. per sq. in. or more, and speeds to 13 knots or more. Size has much to do with economy of transport, and Fitch was quite right when he said that "larger boats could be made to greater advantage".

In conclusion, Mr. Pendred said, "Further economy in cargo ships must be and will be sought. May it not best be found by extension of the known and approved, by higher propeller speeds, higher pressures, higher temperatures, higher piston speeds, better materials making for lighter structures, better under-water form? These will carry the steam engine forward until, its work well done, it surrenders its place to the internal combustion engine, or to some other prime mover which still lies in the womb of time".

Carriage by sea is the cheapest of all forms of transport, and the reduction in cost during the last century has been remarkable. Even thirty years ago, Sir William White said : "When small vessels were used to transport grain from America the freight was $9 s .6 d$. per quarter; now it is $9 d$. per quarter from New York in the large cargo. carriers". 